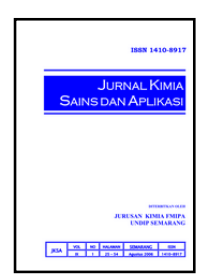

\title{
Uji Aktivitas Isolat L-Asparaginase Dari Rimpang Temulawak (Curcuma xanthorrhiza Roxb) Terhadap Sel Hela
}

\author{
Arthuro Romualdo ${ }^{a}$, Wuryanti ${ }^{\mathrm{a}^{*}}$, Suprihati ${ }^{\mathrm{b}}$ \\ a Biochemistry Laboratory, Chemistry Department, Faculty of Sciences and Mathematics, Diponegoro University, Jalan Prof. \\ Soedarto, Tembalang, Semarang 50275 \\ b ENT-HNS Department, Faculty of Medicine, Diponegoro University \\ * Corresponding author: wuryanti@live.undip.ac.id
}

\section{Article Info}

Keywords:

Asparaginase,

Curcuma

xanthorrhiza Roxb, isolation, HeLa cell

\begin{abstract}
L-asparaginase is a hydrolase enzyme that catalyzes the hydrolysis of asparagine into aspartic acid and ammonia. L-asparaginase is known to help treat cancer by inhibiting the synthesis of cancer cell proteins without damaging normal cells. Methods performed were enzyme isolation including extraction, fractionation with ammonium sulphate; characterization by specific activity test and cytotoxicity test on HeLa cells. The highest specific activity of ammonium sulfate isolate L-asparaginase fraction was found in the fourth fraction of 22,639 units/mg. Furthermore, the fourth fraction was tested on HeLa cells in the cytotoxicity test. Based on the results of the cytotoxicity test, this isolate had inhibitory activity on the growth of HeLa cells with $\mathrm{LC}_{50}$ value of $309.74 \mathrm{ppm}$.

Abstrak
\end{abstract}

Kata kunci:

Asparaginase, temulawak, isolasi, HeLa

\section{Pendahuluan}

Penyakit kanker merupakan penyebab kematian nomor dua di dunia. Sampai saat ini, pengobatan modern yang dilakukan adalah kemoterapi dan radiasi sebagai ganti pembedahan. Kemoterapi dan radiasi menimbulkan efek samping yang dapat membahayakan bagi penderita kanker. Memang pada stadium dini, kemoterapi dan radiasi memberikan hasil yang efektif namun pada stadium lanjut, proses ini kurang bermanfaat atau bahkan dapat membahayakan penderita oleh karena pada stadium lanjut sel kanker menginvasi sel sekitar (metastasis), maka organ yang terkena langsung ataupun sekitarnya dapat terganggu juga. Alasan lain adalah karena kemoterapi menggunakan senyawa kimia intensitas tinggi sehingga dapat mengganggu sel normal dalam radius aktif dari senyawa obat. Sehingga dewasa ini, kemoterapi dimodifikasi dengan menggunakan obat dari bahanbahan alam yang dapat meningkatkan keampuhan kemoterapi namun menurunkan efek sampingnya. Indonesia adalah negara dengan kekayaan bahan alam melimpah, termasuk rempah-rempah seperti jahe, kunyit dan temulawak. Berdasarkan penelitian dari Qing-Long, 2002, diketahui bahwa enzim Lasparaginase dari bakteri E-Coli dapat menghambat pertumbuhan sel kanker leukimia limfoblastik. Enzim Lasparaginae diketahui terkandung dalam banyak organisme, meliputi: bakteri [1], tubuh manusia [2], dan tumbuhan [3]. L-asparaginase mengkatalisis hidrolisis 
L-asparagin menjadi L-aspartat dan amonia. Berdasarkan referensi yang ada, tidak banyak penelitian dalam negeri yang mengembangkan khasiat temulawak sebagai antikanker. Penelitian luar negeri juga belum ada yang menguji potensi antikanker L-asparaginase terhadap sel Hela. Oleh karena itu, penelitian ini bertujuan menguji potensi antikanker L-asparaginase terhadap sel HeLa. Sumber enzim yang digunakan adalah temulawak (Curcuma xanthorrhiza Roxb). Secara khusus, penelitian ini bertujuan untuk mengisolasi enzim L-asparaginase dari temulawak, melakukan pemurnian terhadap isolat, menguji aktivitas spesifik isolat dan isolat dengan aktivitas spesifik tertinggi akan diujikan terhadap sel Hela.

\section{Metodologi}

Bahan. Temulawak, BSA (Bovine Serum Albumin), TCA (Trichloracetic acid), tris-hidroksimetilaminometan, folin-ciocalteau, kalium-natrium tartrat, L-asparagin (Merck), amonium sulfat, raksa(II) klorida, asam klorida, natrium karbonat, kalium iodida, barium (II) klorida, natrium hidroksida, tembaga (II) sulfat, akuades, sel HeLa yang dibiakkan oleh LPPT UGM, larutan dapar natrium fosfat $5 \mathrm{mM} \mathrm{pH} \mathrm{7,2,} \mathrm{larutan} \mathrm{dapar}$ natrium fosfat $\left(\mathrm{NaPO}_{4}{ }^{2-}\right) \quad 5 \quad \mathrm{mM} \quad \mathrm{pH} \quad 7,2$ yang mengandung 0,14 M NaCl, medium RPMI 1640 (Sigma), FBS (Fetal Bovine Serum) 10\% (v/v) (Gibco), larutan MTT dalam media RPMI (Sigma) dan kertas saring yang semuanya berkualitas p.a

Alat. sentrifuge (Centrific-228), inkubator (Memmert), blender (Philip), neraca analitik (Kern 870), pHmeter (Orain-420A), magnetic stirer (Thermolyne Cimarec), kulkas (Sharp), botol semprot, pisau stainlessteel, alat-alat kultur sel, spektrofotometer UVVis (Shimadzu), gelas beker, tabung reaksi, labu ukur, botol vial, corong kaca, mikropipet, pipet tetes, kertas saring, pengaduk, laminar air flow, 96-well plate (Nunc), mikroskop fluoresen dan ELISA reader.

\section{Isolasi Enzim L-asparaginase}

Rimpang temulawak (Curcuma xanthorrhiza Roxb) sebanyak $1000 \mathrm{~g}$ dipotong kecil dan ditambahkan 500 mL buffer Tris-hidroksimetil-aminometan 0,2 $\mathrm{M} \mathrm{pH}$ 8,6 dan dihaluskan dengan blender selama 20 menit. Campuran didiamkan selama 1,5 jam lalu disaring. Filtrat disentrifugasi pada $3400 \mathrm{rpm}$ selama 10 menit. Filtrat hasil proses sentrifugasi disebut ekstrak kasar (EK).

\section{Fraksinasi dengan Amonium Sulfat}

Fraksinasi enzim dilakukan dengan menggunakan garam amonium sulfat dengan 5 tingkat kejenuhan, yaitu $0-20 \%\left(\mathrm{~F}_{1}\right), 20-40 \%\left(\mathrm{~F}_{2}\right), 40-60 \%\left(\mathrm{~F}_{3}\right), 60-80 \%$ $\left(\mathrm{F}_{4}\right), 80-100 \%\left(\mathrm{~F}_{5}\right)$. Amonium sulfat ditimbang sesuai fraksi yang dikehendaki agar diperoleh konsentrasi yang diinginkan, lalu dimasukkan ke dalam larutan ekstrak kasar (EK) sedikit demi sedikit sambil diaduk dengan magnetic stirer dalam penangas es. Campuran didiamkan selama 1 malam dalam lemari es, kemudian disentrifugasi pada $3500 \mathrm{rpm}$ selama 50 menit. Endapan yang diperoleh dipisahkan dari filtrat dan disuspensi dalam $3 \mathrm{~mL}$ buffer Tris-hidroksimetil-aminometan 0,2 $\mathrm{M} \mathrm{pH} \mathrm{8,6.} \mathrm{Endapan} \mathrm{yang} \mathrm{disuspensi} \mathrm{tersebut} \mathrm{disebut}$ Fraksi $1\left(F_{1}\right)$. Filtrat hasil sentrifugasi didiamkan selama 1 malam lalu diproses lagi sesuai prosedur seperti yang dilakukan sebelumnya untuk mendapatkan Fraksi $2\left(\mathrm{~F}_{2}\right)$, Fraksi $3\left(\mathrm{~F}_{3}\right)$, Fraksi $4\left(\mathrm{~F}_{4}\right)$, Fraksi $5\left(\mathrm{~F}_{5}\right)$.

\section{Dialisis dengan Membran Selofan}

Selofan yang berisi suspensi endapan fraksinasi direndam dalam bufer Tris-hidroksimetil-aminometan $0,002 \mathrm{M} \mathrm{pH}=8,6$ pada keadaan dingin dan tiap 2 jam buffer diganti serta diuji kandungan amonium sulfat pada larutan perendam dengan larutan $\mathrm{BaCl}_{2} \quad 0,01 \mathrm{M}$ hingga tidak terbentuk endapan putih. Fraksi yang diujikan pada sel kanker dikeringkan dengan Freeze dryer.

\section{Penentuan Unit Aktivitas Enzim}

Sebanyak 6 tabung reaksi masing-masing diisi $1 \mathrm{~mL}$ larutan $\mathrm{L}$-asparagin $0,1665 \mathrm{M} ; 0,1 \mathrm{~mL}$ endapan suspensi (EK, $F_{1}, F_{2}, F_{3}, F_{4}, F_{5}$ ), dan $0,4 \mathrm{~mL}$ bufer Trishidroksimetil-aminometan $0,2 \mathrm{M} \mathrm{pH}=8,6$ diinkubasi pada $37^{\circ} \mathrm{C}$ selama 30 menit, kemudian ditambah $1 \mathrm{~mL}$ larutan TCA 1,5 M dan disentrifugasi pada $3400 \mathrm{rpm}$ selama 15 menit untuk memisahkan endapannya. Sebanyak 0,25 mL filtrat diambil lalu ditambah dengan 4,25 mL akuades dan 0,5 mL pereaksi Nessler, absorbansi larutan diukur dengan spektrofotometer UVVis. Sebagai kontrol adalah $0,1 \mathrm{~mL}$ endapan yang disuspensi, yang telah dihilangkan aktifitasnya (dengan dipanaskan), ditambah $0,4 \mathrm{~mL}$ bufer Trishidroksimetil-aminometan $0,2 \mathrm{M} \mathrm{pH}=8,5$ dan $0,5 \mathrm{~mL}$ larutan L-asparagin $0,1665 \mathrm{M}$. Aktivitas enzim ditentukan regresi linier terhadap kurva standar amonium sulfat.

\section{Penentuan Kadar Protein}

Sebanyak $0,1 \mathrm{~mL}$ larutan protein hasil fraksinasi (EK, $\mathrm{F}_{1}, \mathrm{~F}_{2}, \mathrm{~F}_{3}, \mathrm{~F}_{4}, \mathrm{~F}_{5}$ ) ditambah $2 \mathrm{~mL}$ Lowry $\mathrm{C}$, diinkubasi pada $37^{\circ} \mathrm{C}$ selama 30 menit sambil sesekali dikocok. Selanjutnya ditambah 0,2 mL Lowry D dan diinkubasi 10 menit pada suhu kamar dengan sesekali dikocok, kemudian diukur absorbansinya. Absorbansi larutan diukur pada panjang gelombang optimum BSA dengan spektrofotometer UV-Vis. Kadar protein ditentukan regresi linier terhadap kurva standar BSA.

\section{Uji Aktivitas Hambat Isolat Terhadap Sel HeLa}

Larutan uji yang telah dibuat disiapkan. Kultur hasil inisiasi dihomogenkan. Kontrol terdiri dari sel, medium RPMI, dan buffer natrium fosfat $5 \mathrm{Mm} \mathrm{pH}=7,2$. Blanko terdiri dari medium RPMI, buffer natrium fosfat $5 \mathrm{mM}$ $\mathrm{pH}=7$,2. Perlakuan untuk uji toksisitas terdiri dari sel, medium RPMI, buffer natrium fosfat $5 \mathrm{mM} \mathrm{pH}=7,2$ dan isolat enzim L-asparaginase. Sampel yang diuji adalah larutan yang dibuat dari serbuk hasil fraksinasi enzim L-asparaginase dengan aktivitas spesifik tertinggi pada beberapa variasi konsentrasi.

\section{Perhitungan Persen Kematian dengan Metode ELISA}

Larutan MTT dimasukkan kedalam sumuran. Sel yang hidup akan membentuk kristal formazan berwarna 
ungu yang intensitasnya dapat diukur dengan ELISA Reader. Absorbansi yang terbaca sebanding dengan jumlah sel hidup.

\section{Analisis Hasil}

Sitotoksisitas variasi konsentrasi sampel enzim Lasparaginase dianalisa dengan menghitung prosentase kematian sel yang diperoleh dari perhitungan menggunakan modifikasi rumus Abbot [4]:

$$
\text { Persen kematian }=\frac{A-B}{A} \times 100 \%
$$

Keterangan:

$\mathrm{A}=$ Nilai rata-rata absorbansi dari beberapa kontrol

$\mathrm{B}=$ Nilai rata-rata absorbansi dari beberapa perlakuan

Efek toksisitas dianalisis dari pengamatan dengan persen kematian. Dengan mengetahui kematian sel kanker, kemudian dicari angka probit melalui kurva dan dibuat persamaan garis :

$$
\mathrm{Y}=\mathrm{AX}+\mathrm{B}
$$

$\mathrm{Y}=$ Angka probit (50)

$\mathrm{X}=$ Nilai $\mathrm{LC}_{50}$

\section{Hasil dan Pembahasan}

\section{Isolasi Enzim L-asparaginase}

Enzim L-asparaginase rimpang temulawak merupakan enzim ekstraseluler, untuk mengisolasinya diekstrak dari jaringan. Ekstraksi dilakukan dengan dihaluskan menggunakan blender dengan buffer yang sesuai sebagai pelarut. Buffer diperlukan untuk mempertahankan pH optimum enzim. Buffer yang digunakan adalah tris- hidroksimetil aminometan. Ekstraksi menghasilkan campuran kuning kecoklatan terdiri dari senyawa-senyawa dan komponen sel dari temulawak. Untuk mendapatkan enzim, dipisahkan antara senyawa-senyawa dan komponen sel selain senyawa. Pertama, dilakukan penyaringan pada untuk memisahkan antara bagian padatan dan larutan. Langkah selanjutnya adalah sentrifugasi. Sentrifugasi bekerja dengan prinsip pengendapan berdasarkan gaya sentrifugal. Hasil akhir diperoleh endapan yang berisi sisa-sisa komponen sel dan filtrat yang berisi protein enzim dan protein non enzim.

Setelah disentrifugasi, dilakukan penyaringan untuk memisahkan endapan dan filtrat. Filtrat hasil penyaringan disebut ekstrak kasar (EK). Salah satu cara pemurnian enzim adalah fraksinasi dengan menggunakan garam. Fraksinasi dilakukan bertingkat menggunakan tingkat kejenuhan garam yang berbeda. Dari variasi konsentrasi garam, diperoleh beberapa fraksi protein. Fraksinasi bertujuan untuk memisahkan protein enzim asparaginase dengan protein lainnya. Metode fraksinasi berdasarkan teori bahwa ada pengaruh dari jumlah penambahan garam yang berbeda terhadap kelarutan protein dalam suatu larutan.

Penambahan garam ke dalam larutan yang mengandung protein menyebabkan kompetisi antara garam dan protein dalam memperebutkan air. Garam akan lebih kuat dalam mengikat air, sehingga protein akan mengendap. Penurunan kelarutan protein akibat naiknya konsentrasi garam yang terjadi pada proses fraksinasi ini disebut salting out. Garam yang digunakan garam amonium sulfat karena sebagian besar protein enzim tahan terhadap garam tersebut, kelarutannya besar dalam air, mempunyai efek menstabilkan terhadap enzim dan mempunyai kekuatan ion yang lebih besar dari pada garam monovalen [5].

Proses fraksinasi dilakukan pada sebuah wadah yang diberikan es batu untuk menjaga suhu lingkungan untuk menghindari denaturasi protein. Denaturasi protein adalah kerusakan enzim oleh karena terputusnya ikatan-ikatan yang menunjang struktur dan protein [6]. Fraksinasi diikuti dengan sentrifugasi untuk memisahkan endapan dan filtrat (supernatan).

Suspensi endapan protein hasil fraksinasi masih mengandung amonium sulfat, maka amonium sulfat dipisahkan dari suspensi dengan dialisis menggunakan membran selofan [7]. Proses dialisis dilakukan dengan merendam membran selofan berisi fraksi enzim pada larutan buffer encer. Untuk mengidentifikasi adanya amonium sulfat dilakukan penambahan Barium klorida $\left(\mathrm{BaCl}_{2}\right)$ dengan larutan diambil sedikit lalu diteteskan larutan $\mathrm{BaCl}_{2}$. Amonium sulfat akan bereaksi dengan $\mathrm{BaCl}_{2}$ menghasilkan endapan $\mathrm{BaSO}_{4}$ yang berwarna putih. Dialisis dihentikan apabila penambahan $\mathrm{BaCl}_{2}$ dalam bufer tidak menimbulkan endapan putih. Dengan demikian diperoleh enzim L-asparaginase yang bebas dari amonium sulfat. Enzim yang akan diujikan terhadap sel kanker dikeringkan dengan menggunakan freeze dryer.

Freeze dryer adalah alat untuk menghilangkan kadar air dan mengawetkan suatu senyawa. Prinsip kerja dari freeze dryer adalah pembekuan material dengan pengurangan tekanan udara dan menambahkan sedikit panas untuk membuat air beku dalam suatu material menyublim sehingga didapat serbuk enzim yang tidak rusak. Setelah freeze dryer diperoleh enzim kering yang akan diujikan pada sel HeLa. Berdasarkan hasil uji aktivitas spesifik, fraksi keempatlah yang akan diujikan pada sel HeLa.

\section{Uji Aktivitas Spesifik Enzim}

Enzim L-asparaginase hasil isolasi ditentukan aktivitasnya dengan mereaksikan enzim tersebut menggunakan substrat yang sesuai. Substrat yang digunakan adalah L-asparagin. Enzim L-asparaginase akan mengkatalisis reaksi hidrolisis L-asparagin menjadi L-aspartat dan amonia $\left(\mathrm{NH}_{3}\right)$.

Aktivitas spesifik enzim L-asparaginase dihitung dari unit aktivitas enzim per mg protein. Satu unit aktivitas enzim L-asparaginase didefinisikan sebagai kemampuan enzim yang membentuk $1 \mu \mathrm{mol} \mathrm{NH}_{4}{ }^{+}$per menit pada kondisi optimum [8]. Aktivitas enzim Lasparaginase diukur dari amonia yang dihasilkan, dan diuji dengan menggunakan pereaksi Nessler menghasilkan senyawa kompleks berwarna coklat kekuningan. Warna tersebut diukur absorbansinya 
dengan spektro UV-Vis dan absorbansi yang terukur kemudian diplotkan pada kurva standar amonium sulfat untuk mengetahui besarnya unit aktivitas yang terdapat pada ekstrak kasar dan tiap-tiap fraksi enzim. Untuk menentukan nilai aktivitas spesifik tidak hanya dipengaruhi oleh unit aktivitas tetapi juga dipengaruhi oleh kadar protein suatu fraksi. Kadar protein pada tiap fraksi diukur dengan metode Lowry [8]. Pada metode ini, protein akan bereaksi dengan pereaksi Lowry, menghasilkan senyawa kompleks berwarna biru dan di plotkan pada kurva standar BSA dan dapat diukur absorbansinya dengan menggunakan spektrofotometer UV-Vis.

Nilai aktifitas spesifik diketahui dari pengukuran unit aktivitas dan kadar protein dari tiap fraksi. Besarnya aktifitas spesifik merupakan rasio dari unit aktivitas dan kadar protein.

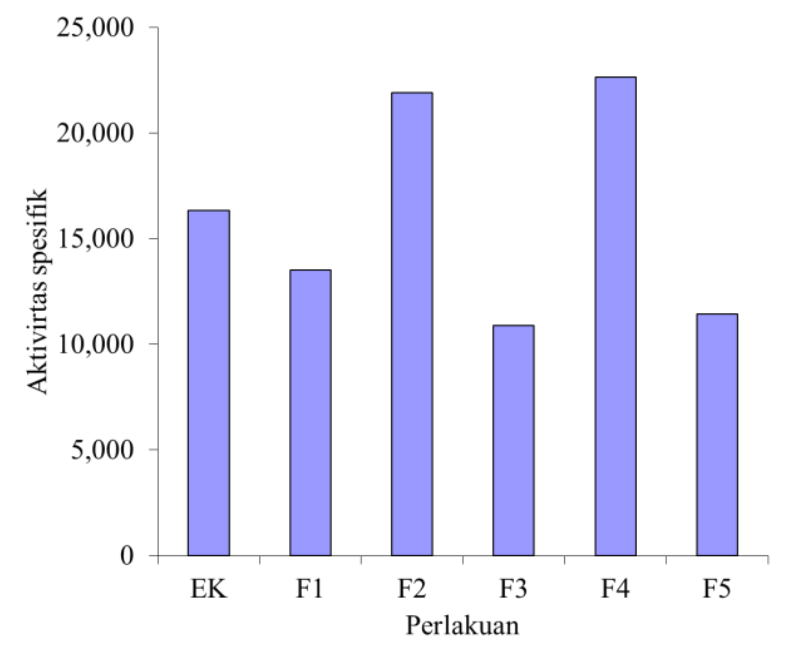

Gambar 1 Grafik aktivitas spesifik L-asparaginase

Fraksi dengan unit aktivitas besar belum tentu aktivitas spesifiknya besar, begitu pula fraksi enzim dengan kadar protein kecil belum tentu aktivitas spesifiknya besar. Aktivitas spesifik ditentukan oleh perbandingan unit aktivitas terhadap kadar protein.

\section{Pengujian Terhadap Sel HeLa}

Isolat di uji pada sel HeLa menggunakan metode ELISA (Enzyme Linked Immunosorbent Assay). Metode MTT adalah suatu metode standar kolorimetri untuk mengukur pertumbuhan sel. Metode ini dapat digunakan untuk menentukan toksisitas agen obat potensial.

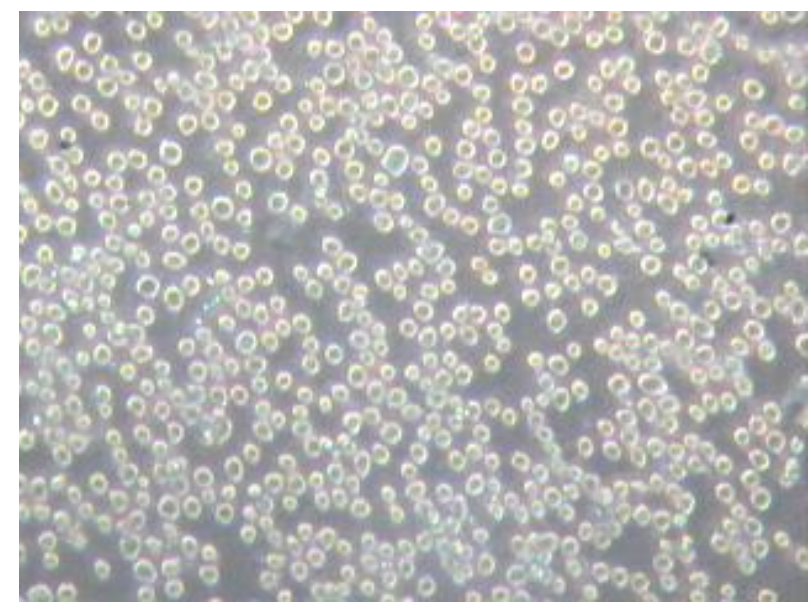

Gambar 2 Sel HeLa

Medium yang digunakan sel HeLa adalah RPMI. Ekstrak yang telah divariasi konsentrasi diujikan terhadap sel HeLa pada sumuran (plate). Plate diinkubasi dalam inkubator $\mathrm{CO}_{2}$ selama 24 jam untuk mengetahui aktivitasnya. Sel HeLa memerlukan bikarbonat sebagai ion bufer untuk mempertahankan pH pada medium kultur.

Prinsip dari metode MTT adalah adanya pemecahan garam dimetiltiazol tetrazolium [3-(4,5-Dimethylthiazol2-yl)-2,5-diphenyl- tetrazolium bromida] oleh sistem enzim suksinat reduktase (suksinat dehidrogenase) pada mitokondria sel hidup sehingga terbentuk kristal formazan berwarna ungu [9]. Semakin tinggi intensitas warna ungu berarti sel hidup semakin banyak. Intensitas dibaca dengan ELISA Reader dan output berupa absorbansi. Semakin banyak kristal formazan yang terbentuk maka semakin tinggi nilai absorbansi yang diperolah dan mengindikasikan kematian yang rendah.

Reaksi MTT dihentikan dengan penambahan $10 \%$ SDS (Sodium Dodecyl Sulfate) dalam 0,01N HCl yang berfungsi melarutkan kristal formazan yang terbentuk. Pengukuran dengan ELISA Reader dilakukan pada panjang gelombang $550 \mathrm{~nm}$ [10]. Absorbansi yang terbaca sebanding dengan jumlah sel yang hidup.

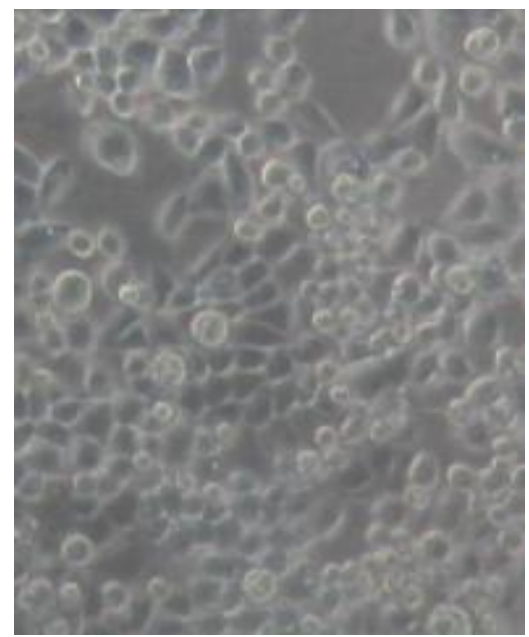

Gambar 3. Foto Sel HeLa 


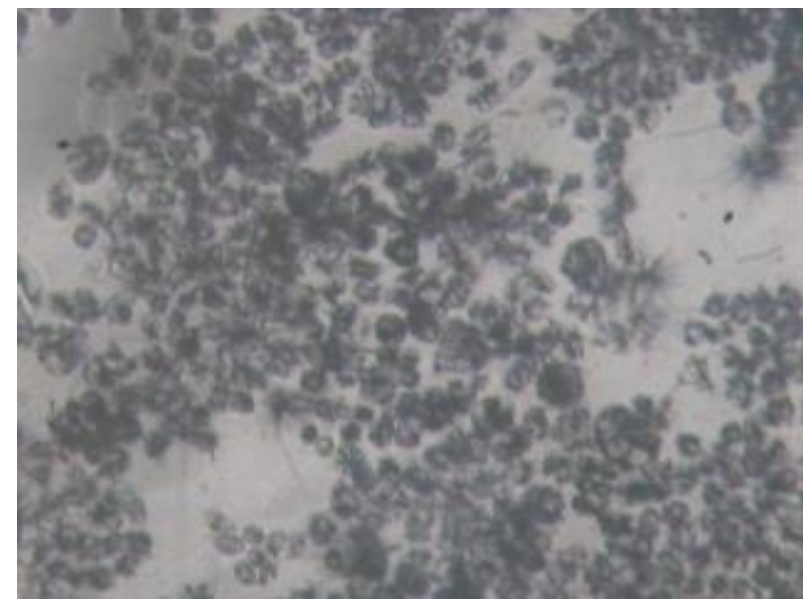

Gambar 4. Sel+Ekstrak (telah mati)

Besarnya penghambatan oleh L-asparaginase pada sel HeLa ditunjukkan pada uji sitotoksisitas oleh besarnya nilai $\mathrm{LC}_{50}$. Nilai $\mathrm{LC}_{50}$ menunjukkan konsentrasi yang digunakan untuk membunuh $50 \%$ dari populasi sel HeLa atau setengah dari jumlah sel HeLa mula-mula.

Tabel 1. Persen Kematian Sel Pada Variasi Konsentrasi

\begin{tabular}{ccc}
\hline $\begin{array}{c}\text { Konsentrasi } \\
(\mathrm{ppm})\end{array}$ & $\begin{array}{c}\text { Persen kematian } \\
(\%)\end{array}$ & $\begin{array}{c}\text { Log } \\
\text { konsentrasi }\end{array}$ \\
\hline 1000 & 102.2 & 3 \\
500 & 67.19 & 2.7 \\
250 & 17.41 & 2.4 \\
125 & 18.3 & 2.1 \\
62.5 & 14.73 & 1.8 \\
31.25 & 18.75 & 1.49 \\
15.6 & 18.75 & 1.19 \\
7.8 & 18.97 & 0.89 \\
3.9 & 14.06 & 0.59 \\
1.95 & 14.51 & 0.29 \\
\hline
\end{tabular}

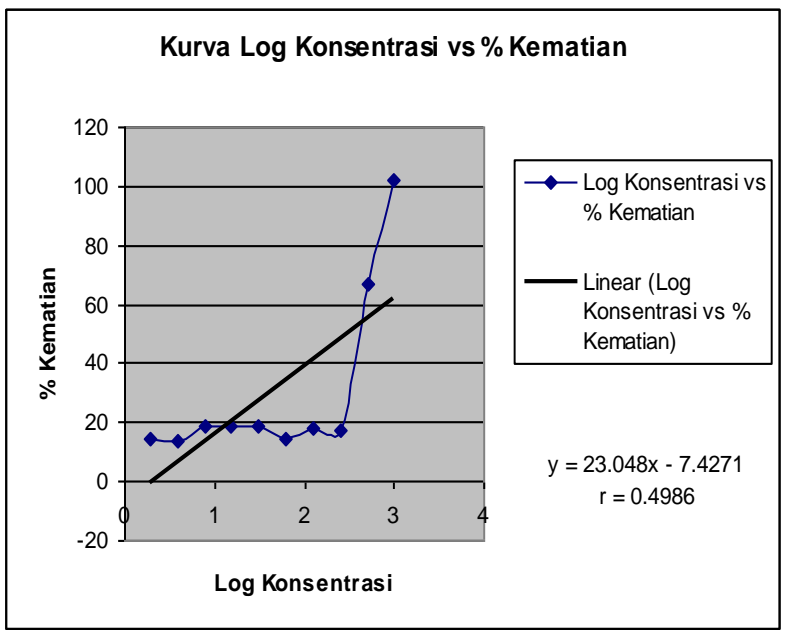

Gambar 5. Kurva Aktivitas Hambat Isolat Lasparaginase Terhadap Sel HeLa

Persamaan regresi linier yang diperoleh dari grafik yaitu $\mathrm{y}=23,048 \mathrm{x}-7,4271$. Persamaan tersebut untuk menghitung nilai $\mathrm{LC}_{50}$ dengan memasukkan nilai 50 sebagai $y$ sehingga didapatkan nilai $x$. Nilai $x$ menunjukan nilai log dari konsentrasi dari fraksi ke-4 enzim L-asparaginase. Nilai $\mathrm{x}$ yang menunjukkan konsentrasi fraksi ke-4 enzim L-asparaginase adalah antilog 2,491 yaitu 309,74. Hal ini berarti kematian dari sel HeLa mencapai 50 \% dengan adanya penambahan enzim L-asparaginase dengan konsentrasi 309,74 ppm.

\section{Kesimpulan}

Enzim L-asparaginase diisolasi dari rimpang temulawak (Curcuma xanthorrhiza Roxb). Isolat memiliki aktivitas spesifik tertinggi pada fraksi ke-4 amonium sulfat (kemurnian 60-80) dengan aktivitas spesifik enzim sebesar 22, 639 unit/mg protein. Isolat fraksi ke4 amonium sulfat memiliki aktivitas penghambatan pada pertumbuhan sel HeLa dengan nilai $\mathrm{LC}_{50}$ sebesar 309, $74 \mathrm{ppm}$.

\section{Daftar Pustaka}

[1] Qing-Long Guo, Min-Shu Wu, Zhen Chen, Comparison of antitumor effect of recombinant Lasparaginase with wild type one in vitro and in vivo, Acta Pharmacologica Sinica, 23, 10, (2002) 946-951

[2] P. Konečná, B. Klejdus, H. Hrstková, Monitoring The Asparaginase Levels in Children with Acute Lymphoblastic Leukaemia Treated with Different Asparaginase Preparations, Scripta Medica, (2004) 55-62

[3] A. A. El-Bessoumy, M. Sarhan, J. Mansour, Production, isolation, and purification of Lasparaginase from Pseudomonas aeruginosa 50071 using solid-state fermentation, Journal of biochemistry and molecular biology, 37, 4, (2004) 387-393

[4] B. N. Meyer, N. R. Ferrigni, J. E. Putnam, L. B. Jacobsen, D. E. Nichols, Jerry L. McLaughlin, Brine shrimp: a convenient general bioassay for active plant constituents, Planta medica, 45, 05, (1982) 3134

[5] Robert K. Scopes, Protein Purification: Principles and Practice, 3rd edition ed., Srpinger, Newyork, 1987.

[6] Albert L. Lehninger, Dasar-dasar biokimia, Erlangga, Jakarta, 2000.

[7] Felix Franks, Characterization of Proteins, Humana Press, 2007.

[8] J. H. Paul, Isolation and characterization of a Chlamydomonas L-asparaginase, Biochemical Journal, 203, 1, (1982) 109-115 http://dx.doi.org/10.1042/bj2030109

[9] R. Ian Freshney, Culture of Animal Cells: A Manual of Basic Technique and Specialized Aplication, Lissing, New York, 1986.

[10] T. Mosmann, Rapid colorimetric assay for cellular growth and survival: application to proliferation and cytotoxicity assays, Journal of immunological methods, 65, 1-2, (1983) 55-63 